\title{
Erratum to: Estrogen augments the $T$ cell-dependent but not the $T$-independent immune response
}

\author{
Mónika Ádori · Endre Kiss · Zsuzsanna Barad • Klaudia Barabás • \\ Edda Kiszely • Andrea Schneider • Dorottya Kövesdi • Erna Sziksz • \\ István M. Ábrahám · János Matkó · Gabriella Sármay
}

Published online: 16 May 2010

(C) Springer Basel AG 2010

\section{Erratum to: Cell Mol Life Sci (2010) 67:1661-1674}

DOI 10.1007/s00018-010-0270-5

In the list of authors, one author was inadvertently left out.

The complete list of authors reads as follows:

Adori M, Kiss E, Barad Z, Barabás K, Kiszely E, Schneider A, Kövesdi D, Sziksz E, Abrahám IM, Matkó J, Sármay G.

The affiliation of Dorottya Kövesdi is: Department of Immunology, Eötvös Loránd University, Budapest, Hungary.

The online version of the original article can be found under doi:10.1007/s00018-010-0270-5.

M. Ádori · Z. Barad · E. Kiszely · A. Schneider · D. Kövesdi ·

E. Sziksz · J. Matkó · G. Sármay ( $₫)$

Department of Immunology, Eötvös Loránd University,

Budapest, Hungary

e-mail: sarmayg@elte.hu; sar7197@mail.iif.hu

Z. Barad · I. M. Ábrahám ( $₫)$

Department of Physiology, Centre for Neuroendocrinology,

University of Otago, Dunedin, New Zealand

e-mail: istvan.abraham@otago.ac.nz

K. Barabás

Proteomics Laboratory, Institute of Biology,

Eötvös Loránd University, Budapest, Hungary

E. Kiss · J. Matkó · G. Sármay

Immunology Research Group of the Hungarian Academy

of Sciences, Eötvös Loránd University, Budapest, Hungary 